\title{
Penentuan Prioritas Perbaikan Jalan Menggunakan Fuzzy C-Means : Studi Kasus Perbaikan Jalan Di Kota Samarinda
}

\author{
Novianti Puspitasari ${ }^{*}$, Rosmasari, Stefanie \\ Program Studi Teknik Informatika, Fakultas Ilmu Komputer dan Teknologi Informasi, Universitas Mulawarman \\ Jl. Barong Tongkok, Kampus Gunung Kelua, Samarinda, Indonesia 75119
}

\begin{abstract}
One of the factors traffic accidents are caused by a damage road. Therefore, road improvements based on the priorities scale is indispensable. In this study implements the Fuzzy CMeans method, a method that is capable to classifying data based on the characteristics. The results showed that the FCM algorithm was able to classify the road improvements into four groups; 1, 2, 3, and 4 priorities. Based on the test results the accuracy of calculations on the data of road damage, there are 8 correct data from 9 trial data or $88.89 \%$, which indicates that the method FCM clustering results and a precise calculation.
\end{abstract}

Keywords - Fuzzy C-Means; damage road; clustering

Abstrak - Kerusakan jalan merupakan salah satu masalah yang menjadi perhatian serius. Hal ini dikarenakan kerusakan jalan merupakan penyebab tingginya angka kecelakaan lalu lintas. Oleh karena itu, diperlukan skala prioritas untuk penentuan prioritas perbaikan jalan. Penelitian ini menerapkan metode Fuzzy C-Means (FCM), yaitu suatu metode yang mampu mengelompokkan data berdasarkan karakteristik yang dimilikinya. Dimana, data kerusakan jalan selama setahun akan dikelompokkan ke dalam 4 kelompok urutan prioritas perbaikan jalan yaitu prioritas 1, prioritas 2, prioritas 3 dan prioritas 4 berdasarkan parameter biaya, kecepatan kendaraan dan kepadatan lalu lintas. Berdasarkan hasil uji akurasi perhitungan pada data kerusakan jalan, terdapat 8 data yang benar dari 9 data uji coba atau sebesar $88,89 \%$ yang menunjukkan bahwa metode FCM memberikan hasil pengelompokkan dan perhitungan yang tepat.

Kata Kunci - Fuzzy C-Means; Kerusakan Jalan; clustering

\section{Pendahuluan}

Kerusakan jalan merupakan salah satu masalah yang menjadi perhatian serius Pemerintah. Hal ini dikarenakan kerusakan jalan merupakan penyebab tingginya angka kecelakaan lalu lintas. Berbagai upaya dalam meminimalisasi terjadinya kecelakaan lalu lintas akibat kerusakan jalan terus dilakukan, termasuk dengan

*) penulis korespondensi (Novianti Puspitasari)

Email: novia.ftik.unmul@gmail.com membentuk tim pemantau perbaikan jalan. Meskipun begitu, upaya perbaikan jalan tidak dapat dilakukan jika prioritas perbaikan jalan tidak merata. Selama ini untuk menentukan prioritas jalan yang harus diperbaiki, pihak Dinas Bina Marga dan Pengairan (DBMP) mendapatkan instruksi dari Kantor Walikota yang merupakan hasil pertimbangan terhadap usulan masyarakat tentang jalan yang sedang rusak. Kemudian, pihak DBMP melakukan survei lapangan sebelum mengambil keputusan. Apabila kondisi jalan cukup parah dan berpotensi mengganggu kelancaran lalu lintas maka jalan tersebut, maka akan mendapat prioritas untuk diperbaiki terlebih dahulu. Hal ini tentu menyulitkan DBMP dalam penentuan prioritas perbaikan jalan karena penentuan prioritas perbaikan jalan yang dilakukan bersifat subyektif. Oleh karena itu diperlukan sebuah sistem yang mampu membantu DBMP untuk menentukan rekomendasi prioritas jalan yang harus diperbaiki terlebih dahulu dengan memperhitungkan berbagai parameter yang ada.

Metode fuzzy clustering, telah banyak diaplikasikan untuk mengelompokkan suatu data berdasarkan kesamaan/kemiripan yang dimilikinya. Salah satu metode fuzzy clustering yang biasa diterapkan adalah Fuzzy Clustering Means (FCM). Dimana, untuk meminimalisasikan fungsi obyektif yang diset dalam proses clustering yang ada pada umumnya, FCM berusaha meminimalisasikan variasi didalam suatu cluster dan memaksimalkan variasi antar cluster [1].

Metode FCM telah banyak digunakan sebagai alat untuk memberikan rekomendasi keputusan berbagai keperluan. Diantaranya, dalam bidang geologi dimana FCM diterapkan untuk mengetahui kondisi cuaca dan pergeseran musim yang terjadi [2]. Dalam bidang pengolahan citra digital dan image, FCM dapat digunakan untuk pendeteksian area tumor otak [3], sistem pendeteksi gangguan pada jaringan komputer [4] dan lain-lain [5, 6]. Selanjutnya, pada bidang pariwisata dimana FCM diterapkan untuk membagi tempat wisata sesuai cluster yang diinginkan, agar dapat memberikan informasi tingkat kunjungan di setiap objek wisata [7]. Di bidang transportasi, FCM digunakan untuk mengelompokkan lalu lintas yang padat di negara perkotaan [8]. Pada bidang pendidikan, FCM digunakan untuk pengelompokan konsentrasi jurusan mahasiswa dengan melihat batas bobot nilai akademis mata kuliah 
tertentu sesuai dengan hasil pengelompokkan yang dilakukan menggunakan metode FCM tanpa mengesampingkan minat personal mahasiswa [9].

Selanjutnya, metode FCM banyak digunakan untuk pembuatan aplikasi yang mendukung pengambilan keputusan, seperti aplikasi penentuan predikat kelulusan mahasiswa berdasarkan data predikat kelulusan seperti jumlah sks, jumlah IPK dan keterangan lulus [10]. Sistem penentuan untuk penerimaan dan penyaluran zakat berdasarkan lima parameter yaitu indeks keluarga, indeks keluarga II, indeks barang, indeks data keluarga dan indeks keimanan [11] Kemudian penerapan FCM dalam sistem pendukung keputusan untuk penerimaan Bantuan Langsung Masyarakat (BLM) PNPM-MPd berdasarkan kriteria kelayakan yang digunakan untuk penentuan prioritas usulan yang akan menghasilkan daftar rangking usulan. Dimana, output sistem berupa perangkingan usulan kegiatan desa serta kategori usulan desa, yaitu layak atau tidaknya usulan tersebut dalam menerima bantuan dari PNPM MPd [12].

Dari beberapa penelitian yang ada, menunjukkan bahwa metode FCM memiliki kemampuan untuk melakukan pengelompokan data yang belum diklasifikasi, kedalam kelas tertentu menurut kesamaan yang dimilikinya, berdasarkan derajat keanggotaan dengan cara minimalisasi nilai fungsi obyektifnya [9]. Sehingga dapat memberikan rekomendasi untuk sebuah pengambilan keputusan.

Oleh karena itu, penelitian ini menerapkan metode FCM untuk mengelompokkan data jalan yang rusak kedalam empat kategori prioritas perbaikan jalan; prioritas 1, prioritas 2, prioritas 3 dan prioritas 4 . Dimana, prioritas 1 adalah kelompok jalan yang akan diperbaiki pada triwulan 1. Prioritas 2 adalah kelompok jalan yang akan diperbaiki pada triwulan 2. Prioritas 3 adalah kelompok jalan yang akan diperbaiki pada triwulan 3. Dan kelompok prioritas 4 adalah kelompok jalan yang akan diperbaiki pada triwulan 4. Adapun hasil rekomendasi prioritas perbaikan jalan nantinya akan diimplementasikan ke dalam sebuah perangkat lunak/sistem sehingga dapat memberikan rekomendasi berupa prioritas perbaikan jalan yang harus diperbaiki terlebih dahulu secara tepat. Lebih lanjut, hasil penelitian diharapkan mampu memberikan rekomendasi kepada pihak yang terkait khususnya DBMP dalam menentukan prioritas perbaikan jalan di kota Samarinda.

Paper ini terdiri dari pendahuluan yang berisi latar belakang, permasalahan dan hasil penelitian sebelumnya yang terkait. Bagian dua terdiri dari metode penelitian yang menjelaskan proses kerja metode FCM. Bagian tiga, hasil dan pembahasan yang menjelaskan temuan dari eksperimen. Hasil penelitan yang dirangkum pada bagian akhir.

\section{Metode Penelitian}

Pada bagian ini akan dijelaskan secara singkat metode FCM, data jalan dan analisis perbandingan hasil yang digunakan dalam penelitian ini.

\section{Metode Fuzzy C-Means (FCM)}

Metode FCM adalah suatu teknik peng-cluster-an data. Dimana, keberadaan tiap-tiap data dalam suatu cluster ditentukan oleh derajat keanggotaan [13]. Konsep dasar Fuzzy Clustering yang pertama kali adalah menentukan pusat cluster, yang akan menandai lokasi rata-rata untuk tiap-tiap cluster. Pada kondisi awal, pusat cluster ini masih belum akurat. Tiap-tiap titik data memiliki derajat keanggotaan untuk tiap-tiap cluster. Dengan cara memperbaiki pusat cluster dan derajat keanggotaan tiap-tiap titik data secara berulang, maka akan dapat dilihat bahwa pusat cluster akan bergerak menuju lokasi yang tepat. Perulangan ini didasarkan pada minimasi fungsi obyektif yang menggambarkan jarak dari titik data yang diberikan ke pusat cluster yang terbobot oleh derajat keanggotaan titik data tersebut. Output dari FCM bukan merupakan fuzzy inference system, namun merupakan deretan pusat cluster dan beberapa derajat keanggotaan untuk tiap-tiap titik data. Informasi ini dapat digunakan untuk membangun suatu fuzzy inference system [14]. Berikut ini flowchart dari metode FCM seperti terlihat pada Gambar 1.

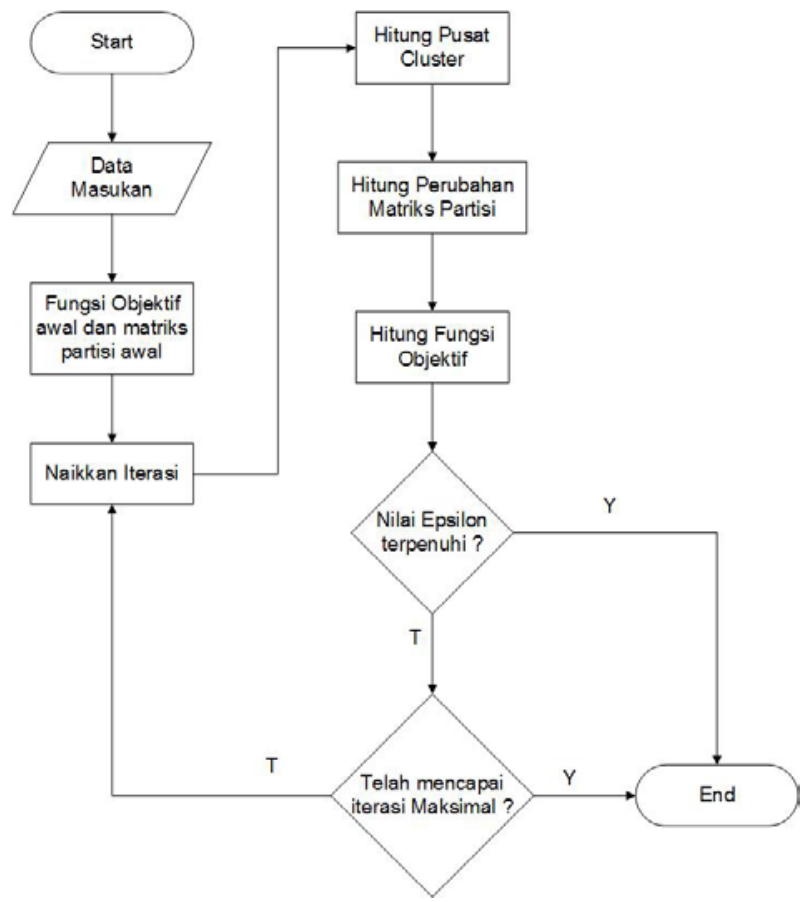

Gambar 1. Flowchart metode FCM

Sedangkan, algoritma pada metode FCM yang digunakan adalah sebagai berikut [9]:

1. Input data yang akan di-cluster $\mathrm{X}$, berupa matriks berukuran $n x m$ ( $n=$ jumlah sampel data, $m=$ atribut 
data). $\mathrm{X}_{\mathrm{ij}}=$ data sampel ke-i $\left(i=1,2_{z} \ldots n\right)$, atribut ke- $j$ $(j=1,2, \ldots n n)$

2. Selanjutnya tentukan nilai-nilai awal perhitungan seperti:

Jumlah cluster

Pangkat

$=\mathrm{C}$

Maksimum Iterasi

$=w ;$

=MaksIter;

Error terkecil yang diharapkan $=\xi$

Fungsi obyektif awal $\quad=P_{0}=0 ;$

Iterasi awal

$=t=1$;

3.

angkitkan bilangan random dalam bentuk elemen matriks partisi awal U $\mu_{i k}=1,2, \ldots, n ; k=1,2, \ldots{ }_{n} c ;$ kemudian hitunglah jumlah setiap kolom dengan persamaan (1).

$$
Q_{i}=\sum_{k=1}^{c} \mu_{i k}
$$

Dimana :

$\mu_{i k}:$ derajat keanggotaan

$Q_{i}:$ Jumlah nilai derajat keanggotaan perkolom $=1$ dengan $i=1{ }_{x} 2_{x a x} n_{s}$

Selanjutnya tentukan nilai matriks partisi awal, dengan persamaan (2).

$$
\mu_{i k}=\frac{\mu_{i k}}{Q_{i}}
$$

4. Hitung pusat cluster ke- $k: V_{k j}$, dimana $k=1,2, \ldots, c_{s}$ dan $j=1,2, \ldots, n_{s}^{x}$ dengan persamaan (3)

$$
V_{k j}=\frac{\sum_{i=0}^{n}\left(\left(\mu_{i k}\right)^{w} * X_{i j}\right)}{\sum_{i=0}^{n}\left(\mu_{i k}\right)^{w}}
$$

Dimana :

$V$ : pusat cluster

$X_{\mathrm{i}}$ : parameter ke-i

5. Selanjutnya, lakukan perhitungan nilai fungsi obyektif pada iterasi ke- $t\left(P_{t}\right)$, dengan persamaan (4).

$$
P_{i}=\sum_{i=1}^{n} \sum_{k=1}^{n}\left(\left[\sum_{i=1}^{m}\left(X_{i j i}-V_{k j}\right)^{2}\right]\left(\mu_{i k}\right)^{\mathrm{w}}\right)
$$

Dimana $P_{\mathrm{t}}$ : nilai fungsi obyektif iterasi ke- $t$
6. Hitung perubahan matriks partisi U, dengan persamaan (5).

$$
\begin{aligned}
& x_{i k}=\left[\sum_{i=1}^{m}\left(X_{i j}-V_{k j}\right)^{2}\right]^{\frac{-1}{\pi-1}} \\
& \sum_{k=1}^{\infty}\left[\left[\sum_{j=1}^{m}\left(X_{i j}-V_{k j}\right)^{2}\right]^{\frac{-1}{\pi-2}}\right.
\end{aligned}
$$

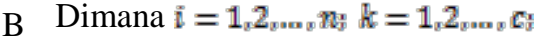

7. Langkah terakhir adalah dengan mengecek kondisi berhenti, dengan ketentuan sebagai berikut: 1.

ika : $\left(\left|P_{t}-P_{t-1}\right|<\xi\right)$ atau $t>$ Maxlter maka berhenti;

2.

ika tidak : $t=t+1$, ulangi langkah ke-4.

\section{Datasets}

\begin{tabular}{|c|c|c|c|c|}
\hline No & Nama Jalan & $\begin{array}{l}\text { Pagu Dana/ } \\
\text { Biaya (Rp) }\end{array}$ & $\begin{array}{l}\text { Kecepatan } \\
\text { Kendaraan } \\
(\mathrm{m} / \mathrm{s}) \\
\end{array}$ & $\begin{array}{l}\text { Kepadatan } \\
\text { Lalu Lintas }\end{array}$ \\
\hline 1 & $\begin{array}{l}\text { Jalan Revolusi } \\
\text { Karang Paci }\end{array}$ & 130.433 .000 & 25 & 35 \\
\hline 2 & $\begin{array}{l}\text { Jalan Masuk } \\
\text { Puskemas } \\
\text { Sempaja }\end{array}$ & 160.520 .000 & 15 & 45 \\
\hline 3 & $\begin{array}{l}\text { Jalan } \\
\text { Mulawarman } \\
\text { Bayur }\end{array}$ & 163.000 .000 & 20 & 15 \\
\hline 4 & $\begin{array}{l}\text { Jalan Rapak } \\
\text { Indah } 3 \text { Jalur }\end{array}$ & 179.240 .000 & 20 & 30 \\
\hline 5 & $\begin{array}{l}\text { Jalan Padat } \\
\text { Karya }\end{array}$ & 155.256 .000 & 10 & 26 \\
\hline 6 & $\begin{array}{l}\text { Jalan } \\
\text { Damanhuri 5a }\end{array}$ & 160.000 .000 & 20 & 35 \\
\hline 7 & $\begin{array}{l}\text { Jalan Adam } \\
\text { Malik Perum } \\
\text { Citra Griya }\end{array}$ & 163.700 .000 & 25 & 34 \\
\hline 8 & $\begin{array}{l}\text { Jalan Lempake } \\
\text { Jaya }\end{array}$ & 143.020 .000 & 15 & 30 \\
\hline 9 & $\begin{array}{l}\text { Jalan } \\
\text { Marhusin }\end{array}$ & 155.000 .000 & 25 & 22 \\
\hline
\end{tabular}

Penelitian ini menggunakan datasets pengujian berupa data jalan yang rusak di Kota Samarinda selama satu tahun yaitu tahun 2015-2016. Data jalan yang rusak dapat dilihat pada Tabel 1.

Tabel 1. Data Jalan Rusak

Dari Tabel 1 diatas dapat diperoleh informasi bahwa terdapat tiga parameter yang menjadi dasar dalam penentuan prioritas perbaikan jalan, yaitu parameter biaya, kecepatan kendaraan dan kepadatan lalu lintas. Adapun, pagu dana/biaya menjelaskan mengenai perkiraan biaya yang akan dikeluarkan dalam proses perbaikan jalan. Sedangkan, kecepatan kendaraan menjelaskan mengenai kecepatan kendaraan yang 
melewati jalan tersebut selama proses survei lapangan berlangsung. Dan, kepadatan lalu lintas menjelaskan mengenai banyaknya kendaraan yang lewat selama proses survei berlangsung.

\section{Analisis Uji Hasil Perhitungan}

Pada tahap ini akan dilakukan uji validasi hasil perhitungan untuk memastikan hasil dari sistem telah sesuai dengan kebutuhan DBMP. Adapun cara yang dilakukan adalah dengan membandingkan hasil pengelompokkan jalan yang dilakukan oleh DBMP dengan hasil pengelompokkan jalan dari sistem yang menerapkan metode FCM. Pada pengujian ini data yang digunakan adalah data pengelompokkan prioritas perbaikan jalan tahun 2015. Setelah melakukan pembandingan, dilakukan perhitungan tingkat validasi sistem untuk mengetahui keakuratan perhitungan yang dilakukan oleh sistem berdasarkan formula pada persamaan (6) berikut.

Tasil $=\frac{\text { Jumlah hasil pengujion bernilaiT }}{n} \times 100 \%$

Dimana, $n$ adalah jumlah data, sedangkan $\mathrm{T}$ adalah nilai True untuk hasil pengujian bernilai sama antara hasil keputusan dengan metode FCM dan hasil keputusan secara manual.

\section{HASIL DAN PEMBAHASAN}

Pada sub bagian ini, akan diuraikan hasil pengujian metode FCM yang diujikan pada data jalan yang rusak. Langkah pertama yaitu menetapkan jumlah cluster. Dalam penelitian ini data jalan akan dikelompokkan ke dalam 4 cluster dengan maksimum iterasi sebanyak 100 kali. Lebih lanjut, dalam proses clustering, parameter biaya dijadikan sebagai $X_{i 1}$, parameter kecepatan kendaraan dijadikan sebagai $X_{i 2}$ dan parameter kepadatan lalu lintas dijadikan sebagai $X_{\text {ia }}$. Dari clustering yang dilakukan akan diperoleh hasil berupa nilai fungsi obyektif selama iterasi, pusat cluster serta derajat keanggotaan jalan untuk setiap cluster pada iterasi terakhir. Di dalam penelitian ini, proses iterasinya berhenti pada iterasi ke-35 karena nilai fungsi obyektif $\left(\left|P_{t}-P_{t-1}\right|<\xi\right)$, sehingga nilai fungsi obyektif yang diperoleh pada iterasi terakhir (iterasi ke-35) adalah 63,660,045,366,021. Hasil clustering yang dilakukan adalah sebagai berikut.

1. Nilai fungsi obyektif selama 35 iterasi yang terlihat pada Tabel 2.

Tabel 2. Fungsi obyektif selama 35 iterasi

\begin{tabular}{cc}
\hline Iterasi Ke- & Fungsi Obyektif \\
\hline 1 & $429,945,858,180,009$ \\
2 & $154,209,409,764,970$ \\
\hline
\end{tabular}

\begin{tabular}{cc}
\hline 3 & $943,619,106,471,569$ \\
$:$ & $:$ \\
$:$ & $:$ \\
$:$ & $:$ \\
35 & $63,660,045,366,021$ \\
\hline
\end{tabular}

2. Derajat keanggotaan jalan untuk setiap cluster pada iterasi terakhir (iterasi ke-35) pada Tabel 3.

Tabel 3. Derajat Keanggotaan iterasi terakhir

\begin{tabular}{|c|c|c|c|c|c|}
\hline \multirow[t]{2}{*}{ No } & \multirow[t]{2}{*}{ Nama Jalan } & \multicolumn{4}{|c|}{ Derajat Keanggotaan } \\
\hline & & C1 & $\mathrm{C} 2$ & C3 & C4 \\
\hline \multirow[t]{2}{*}{1} & Revolusi & 0,0045 & 0,0019 & 0,0078 & 0,9859 \\
\hline & Karang Paci & & & & \\
\hline \multirow[t]{3}{*}{2} & Masuk & 0,9567 & 0,0041 & 0,0374 & 0,0018 \\
\hline & Puskemas & & & & \\
\hline & Sempaja & & & & \\
\hline \multirow[t]{3}{*}{3} & Jalan & 0,9723 & 0,0058 & 0,0202 & 0,0016 \\
\hline & Mulawarman & & & & \\
\hline & Bayur & & & & \\
\hline 4 & $\begin{array}{l}\text { Jalan Rapak Indah } \\
3 \text { Jalur }\end{array}$ & 0,0000 & 1,0000 & 0,0000 & 0,0000 \\
\hline 5 & Jalan Padat Karya & 0,0207 & 0,0015 & 0,9761 & 0,0017 \\
\hline 6 & $\begin{array}{l}\text { Jalan Damanhuri } \\
5 a\end{array}$ & 0,9036 & 0,0075 & 0,0852 & 0,0037 \\
\hline \multirow[t]{2}{*}{7} & Jalan Adam Malik & 0,9406 & 0,0150 & 0,0407 & 0,0037 \\
\hline & Perum Citra Griya & & & & \\
\hline 8 & $\begin{array}{l}\text { Jalan Lempake } \\
\text { Jaya }\end{array}$ & 0,1385 & 0,0371 & 0,3811 & 0,4432 \\
\hline 9 & Jalan Marhusin & 0,0103 & 0,0008 & 0,9880 & 0,0009 \\
\hline
\end{tabular}

Tabel 3 diatas menunjukkan derajat keanggotaan setiap rekomendasi jalan rusak dalam setiap cluster. dapat diperoleh informasi mengenai kecenderungan data untuk masuk ke cluster mana. Derajat keanggotaan terbesar menunjukkan kecenderungan tertinggi jalan untuk masuk menjadi anggota cluster. Sebagai contoh untuk data jalan ke-3, dapat menjadi:

i. Anggota cluster pertama (C1) dengan derajat keanggotaan 0,9723.

ii. Anggota cluster kedua (C2) dengan derajat keanggotaan 0,0058.

iii. Anggota cluster ketiga (C3) dengan derajat keanggotaan 0,0202 .

iv. Anggota cluster keempat (C4) dengan derajat keanggotaan 0,0016.

Berdasarkan data diatas, dapat dilihat bahwa nilai derajat keanggotaan terbesarnya terletak di cluster pertama, sehingga data jalan ke-3 yaitu jalan Mulawarman Bayur akan dimasukkan ke dalam cluster pertama (C1). Hasil selengkapnya pengelompokkan data jalan rusak ke dalam 4 cluster dapat dilihat pada Tabel 4

Tabel 4. Hasil Clustering

\begin{tabular}{|c|c|c|c|c|c|}
\hline \multirow[t]{2}{*}{ No } & \multicolumn{4}{|c|}{ Derajat Keanggotaan } & \multirow{2}{*}{$\begin{array}{c}\text { Data } \\
\text { Masuk } \\
\text { Cluster }\end{array}$} \\
\hline & C1 & $\mathrm{C} 2$ & C3 & C4 & \\
\hline 1 & 0,0045 & 0,0019 & 0,0078 & 0,9859 & 4 \\
\hline 2 & 0,9567 & 0,0041 & 0,0374 & 0,0018 & 1 \\
\hline
\end{tabular}




\begin{tabular}{llllll}
\hline 3 & 0,9723 & 0,0058 & 0,0202 & 0,0016 & 1 \\
4 & 0,0000 & 1,0000 & 0,0000 & 0,0000 & 2 \\
5 & 0,0207 & 0,0015 & 0,9761 & 0,0017 & 3 \\
6 & 0,9036 & 0,0075 & 0,0852 & 0,0037 & 1 \\
7 & 0,9406 & 0,0150 & 0,0407 & 0,0037 & 1 \\
8 & 0,1385 & 0,0371 & 0,3811 & 0,4432 & 4 \\
9 & 0,0103 & 0,0008 & 0,9880 & 0,0009 & 3 \\
\hline
\end{tabular}

Selanjutnya, dari Tabel 4 diatas dapat diperoleh informasi sebagai berikut:

a. Cluster 1 beranggotakan empat jalan yaitu jalan masuk puskesmas sempaja, jalan mulawarman bayur, jalan damanhuri 5a, dan jalan adam malik perum Citra Griya.

b. Cluster 2 beranggotakan hanya satu jalan yaitu jalan rapak indah 3 jalur penguripan.

c. Cluster 3 beranggotakan jalan padat karya dan jalan marhusin.

d. Cluster 4 beranggotakan jalan revolusi karang paci dan jalan Lempake Jaya.

3. Nilai pusat cluster pada iterasi terakhir pusat cluster $V_{k j}$ yang dihasilkan $k=1,2,3$ dengan $j=1,2,3$ ditampilkan oleh Tabel 5 .

Tabel 5. Pusat cluster iterasi terakhir

\begin{tabular}{cccc}
\hline $\mathbf{V}_{\mathbf{k i}}$ & $\mathbf{V}_{\mathbf{i 1}}$ & $\mathbf{V}_{\mathbf{i} 2}$ & $\mathbf{V}_{\mathbf{i} 3}$ \\
\hline Cluster 1 & $161,746,847,94$ & 19,93 & 32,00 \\
Cluster 2 & $179,184,437,19$ & 19,99 & 30,00 \\
Cluster 3 & $154,311,467,01$ & 17,42 & 24,45 \\
Cluster 4 & $132,550,311,41$ & 23,32 & 34,16 \\
\hline
\end{tabular}

Berdasarkan data pada Tabel 5, dapat diperoleh mengenai nilai pusat cluster. Nilai pusat cluster merupakan nilai dari koordinat ke-4 titik pusat cluster dan memberikan informasi garis besar tiap cluster yaitu:

a. Cluster 1 berisi rekomendasi jalan dengan perkiraan biaya perbaikan Rp 161,746,847; Kecepatan kendaraan yang melewati jalan tersebut sekitar 19.93 $\mathrm{m} / \mathrm{s}$; dan memiliki sekitar 32 kendaraan yang memadati jalan selama survei.

b. Cluster 2 berisi rekomendasi jalan dengan perkiraan biaya perbaikan Rp 179,184,437; Kecepatan kendaraan yang melewati jalan tersebut sekitar 20 $\mathrm{m} / \mathrm{s}$; dan memiliki sekitar 30 kendaraan yang memadati jalan selama survei.

c. Cluster 3 berisi rekomendasi jalan dengan perkiraan biaya perbaikan Rp 154,311,467; Kecepatan kendaraan yang melewati jalan tersebut sekitar 17.7 $\mathrm{m} / \mathrm{s}$; dan memiliki sekitar 24 kendaraan yang memadati jalan selama survei.

d. Cluster 4 berisi rekomendasi jalan dengan perkiraan biaya perbaikan Rp 132,550,311; Kecepatan kendaraan yang melewati jalan tersebut sekitar 23.32 $\mathrm{m} / \mathrm{s}$; dan memiliki sekitar 34 kendaraan yang memadati jalan selama survei.
4. Dari hasil pusat cluster iterasi terakhir dapat diperoleh informasi mengenai kecenderungan cluster untuk masuk kedalam urutan prioritas perbaikan jalan. Dimana, urutan prioritas perbaikan jalan ditentukan berdasarkan parameter kepadatan lalu lintas. Hal ini dikarenakan parameter tersebut merupakan parameter utama dan parameter yang sangat berhubungan langsung dengan masyarakat. Adapun rentang nilai dari parameter kepadatan lalu lintas untuk urutan prioritas perbaikan jalan adalah sebagai berikut:

1. Kurang diprioritaskan, dimana jumlah kendaraan kurang dari 25 buah kendaraan per menit.

2. Prioritas, dimana jumlah kendaraan berada pada rentang 25 - 30 kendaraan per menit.

3. Sangat diprioritaskan, dimana jumlah kendaraan lebih dari 30 kendaraan per menit.

Berdasarkan data pada Tabel 5 , dapat disimpulkan bahwa:

a. Prioritas perbaikan jalan ke-1 adalah cluster 4 (C4) dengan jumlah kendaraan 34.

b. Prioritas perbaikan jalan ke-2 adalah cluster 1 (C1) dengan jumlah kendaraan 32.

c. Prioritas perbaikan jalan ke-3 adalah cluster 2 (C2) dengan jumlah kendaraan 30.

d. Prioritas perbaikan jalan ke-4 adalah cluster 3 (C4) dengan jumlah kendaraan 24.

Langkah terakhir dari proses clustering yaitu mengelompokkan data jalan ke dalam urutan prioritas perbaikan jalan. Penentuan urutan prioritas didasarkan pada kelompok jalan yang memiliki jumlah kendaraan terbanyak. Hasil pengelompokkan prioritas perbaikan jalan selengkapnya dapat dilihat pada Tabel 6 .

Tabel 6. Hasil prioritas perbaikan jalan

\begin{tabular}{|c|c|c|c|}
\hline No & Nama Jalan & Cluster & Prioritas \\
\hline 1 & $\begin{array}{ll}\text { Jalan } & \text { Revolusi }\end{array}$ & $\mathrm{C} 4$ & Prioritas ke-1 \\
\hline & Karang Paci & & \\
\hline 2 & Jalan Masuk & C1 & Prioritas ke-2 \\
\hline & Puskemas Sempaja & & \\
\hline 3 & $\begin{array}{l}\text { Jalan Mulawarman } \\
\text { Bayur }\end{array}$ & C1 & Prioritas ke-2 \\
\hline 4 & $\begin{array}{l}\text { Jalan Rapak Indah } \\
3 \text { Jalur }\end{array}$ & $\mathrm{C} 2$ & Prioritas ke-3 \\
\hline 5 & Jalan Padat Karya & C3 & Prioritas ke-4 \\
\hline 6 & $\begin{array}{l}\text { Jalan Damanhuri } \\
5 a\end{array}$ & C1 & Prioritas ke-2 \\
\hline 7 & $\begin{array}{l}\text { Jalan Adam Malik } \\
\text { Perum Citra Griya }\end{array}$ & C1 & Prioritas ke-2 \\
\hline 8 & Lempake & $\mathrm{C} 4$ & Prioritas ke-1 \\
\hline 9 & Jalan Marhusin & C3 & Prioritas ke-4 \\
\hline
\end{tabular}

berikut: 
a. Prioritas perbaikan jalan ke-1 adalah kelompok jalan yang termasuk kedalam cluster 4 (C4), yaitu jalan Revolusi Karang Paci dan Jalan Lempake Jaya. Kelompok ini direkomendasikan untuk diperbaiki pada triwulan 1 .

b. Prioritas perbaikan jalan ke-2 adalah kelompok jalan yang termasuk kedalam cluster 1 (C1), yaitu Jalan Masuk Puskesmas Sempaja, Jalan Mulawarman Bayur, Jalan Damanhuri 5a dan Jalan Adam Malik Perum Citra Griya. Kelompok ini direkomendasikan untuk diperbaiki pada triwulan 2.

c. Prioritas perbaikan jalan ke-3 adalah kelompok jalan yang termasuk kedalam cluster 2 (C2), yaitu jalan Rapak Indah 3 Jalur Panguripan. Kelompok ini direkomendasikan untuk diperbaiki pada triwulan 3.

d. Prioritas perbaikan jalan ke-4 adalah kelompok jalan yang termasuk kedalam cluster 3 (C3), yaitu jalan Jalan Padat Karya dan Jalan Marhusin. Kelompok ini direkomendasikan untuk diperbaiki pada triwulan 4.

Berdasarkan hasil pengelompokkan prioritas perbaikan jalan yang telah dilakukan dengan menggunakan metode FCM didapatkan hasil bahwa jalan yang berhak mendapat prioritas untuk diperbaiki terlebih dahulu adalah jalan Revolusi Karang Paci dan Jalan Lempake Jaya.

\section{Implementasi Sistem}

Implementasi sistem menggambarkan tampilan dari sistem yang dibangun yaitu implementasi sistem penentuan prioritas perbaikan jalan. Tampilan halaman depan sistem ditunjukkan oleh Gambar 2.
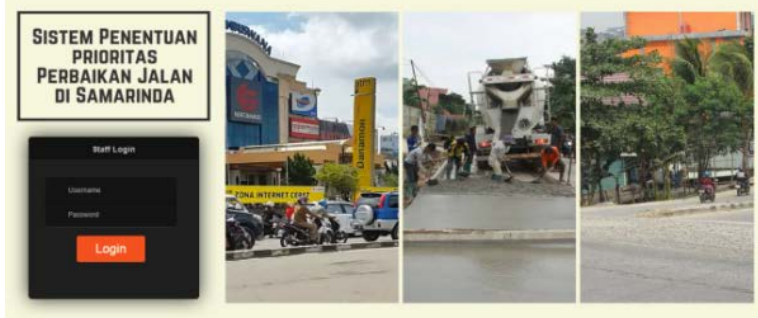

\section{Gambar 2. Tampilan halaman depan sistem}

Tampilan selanjutnya adalah tampilan halaman utama sistem. Halaman ini akan muncul setelah user melakukan login. Halaman ini berisi informasi mengenai alur untuk menjalankan sistem dan tampilan menu-menu yang terdapat pada sistem yang ditunjukkan oleh Gambar 3.

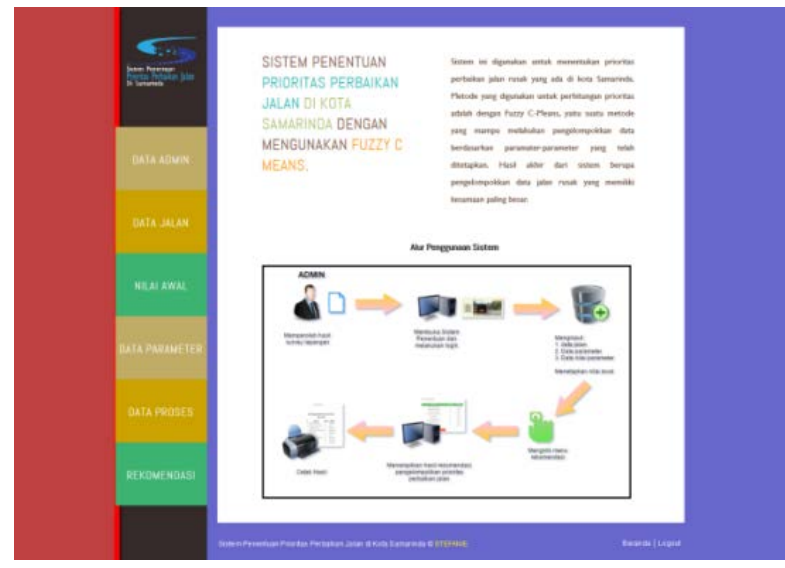

Gambar 3. Tampilan menu sistem

Tampilan menu data jalan, menu data parameter, menu data nilai parameter dan data nilai awal ditunjukkan oleh Gambar 4.

\begin{tabular}{|cccccc}
\hline No & Nama Jalan & Parameter & Nilai & \multicolumn{2}{c}{ Action } \\
\hline 1 & Jalan Revolusi Karang Paci & Kecepatan & 25 & & 而 \\
\hline 2 & Jalan Revolusi Karang Paci & Biaya & 130433000 & 而 \\
\hline 3 & Jalan Revolusi Karang Paci & Kepadatan & 35 & 而
\end{tabular}

NILAI AWAL

\begin{tabular}{|cccc|}
\hline Jumlah Cluster & Maksimum Iterasi & Pembobot & Action \\
\hline 4 & 100 & 2 &
\end{tabular}

Gambar 4. Tampilan menu jalan, menu parameter, menu nilai parameter dan menu nilai awal

Tampilan menu rekomendasi ditunjukkan oleh Gambar 5.

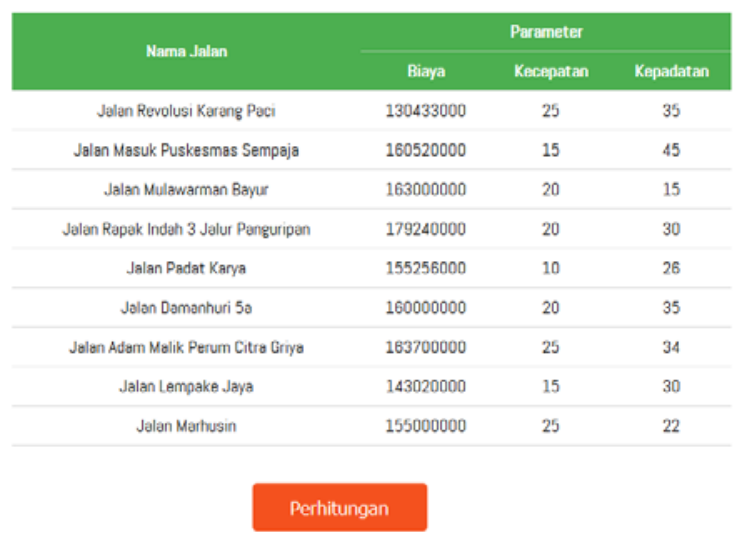

Gambar 5. Tampilan menu rekomendasi

Tampilan menu hasil pengelompokkan data jalan ditunjukkan oleh Gambar 6. 


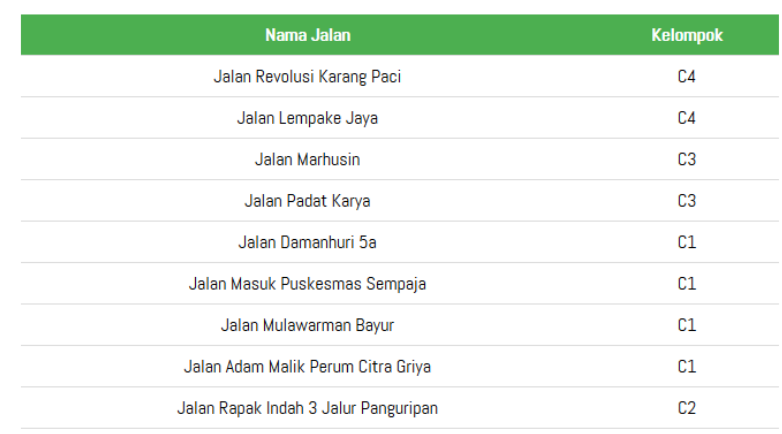

Gambar 6. Tampilan menu hasil pengelompokkan

Tampilan menu pengurutan prioritas perbaikan jalan dapat dilihat pada Gambar 7.

KESIMPULAN URUTAN PRIORITAS JALAN

\begin{tabular}{ccc}
\hline Prioritas & Kelompok & Jumlah Kendaraan \\
\hline Prioritas ke -1 & $\mathrm{C} 4$ & 34 kendaraan yang lewat selama survey \\
\hline Prioritas ke -2 & $\mathrm{C} 1$ & 32 kendaraan yang lewat selama survey \\
\hline Prioritas ke -3 & $\mathrm{C} 2$ & 30 kendaraan yang lewat selama survey \\
\hline Prioritas ke -4 & $\mathrm{C} 3$ & 24 kendaraan yang lewat selama survey \\
\hline
\end{tabular}

Urutan prioritas ditentukan berdasarkan parameter utama, yaitu kepadatan lalu lintas

Gambar 7. Tampilan menu urutan prioritas perbaikan jalan

Dari Gambar 7 diatas, menunjukkan bahwa hasil pengurutan prioritas perbaikan jalan yang dilakukan oleh sistem sama dengan hasil perhitungan yang dilakukan tanpa menggunakan sistem.

\section{Analisis Uji Hasil Perhitungan}

Analisis uji hasil perhitungan dilakukan untuk melihat seberapa besar perbedaan antara hasil prioritas perbaikan jalan yang ditentukan oleh DBMP dengan sistem yang menerapkan metode FCM. Hasil perbandingan dapat dilihat pada Tabel 7.

Tabel 7. Hasil analisis perbandingan

\begin{tabular}{lccc}
\hline \multicolumn{1}{c}{ Nama Jalan } & \multicolumn{2}{c}{ Hasil Pengelompokkan } & Ket \\
\cline { 2 - 3 } & DBMP & Sistem & (T/F) \\
\hline Jalan Revolusi Karang Paci & Prioritas 1 & Prioritas 1 & $\mathrm{T}$ \\
Jalan Masuk Puskemas & Prioritas 2 & Prioritas 2 & $\mathrm{T}$ \\
Sempaja & & & \\
Jalan Mulawarman Bayur & Prioritas 2 & Prioritas 2 & $\mathrm{T}$ \\
Jalan Rapak Indah 3 Jalur & Prioritas 3 & Prioritas 3 & $\mathrm{T}$ \\
Jalan Padat Karya & Prioritas 4 & Prioritas 4 & $\mathrm{T}$ \\
Jalan Damanhuri 5a & Prioritas 2 & Prioritas 2 & $\mathrm{T}$ \\
Jalan Adam Malik Perum & Prioritas 3 & Prioritas 2 & $\mathrm{F}$ \\
Citra Griya & & & \\
Jalan Lempake Jaya & Prioritas 1 & Prioritas 1 & $\mathrm{T}$ \\
Jalan Marhusin & Prioritas 4 & Prioritas 4 & $\mathrm{T}$ \\
\hline
\end{tabular}

*Ket: $\mathrm{T}=$ True $; \mathrm{F}=$ False
Pada Tabel 7, terlihat bahwa terdapat 1 data jalan yang memiliki nilai false. Dimana, nilai false ini menunjukkan perbedaan antara hasil keputusan menggunakan sistem dengan hasil keputusan yang dilakukan oleh DBMP. Selanjutnya, untuk mengetahui seberapa besar persentase perbedaan hasil pengelompokkan data, dilakukan perhitungan menggunakan persamaan (6) seperti berikut ini.

$$
\text { Hasil }=\frac{8}{9} \times 100 \%=88,89 \%
$$

Berdasarkan hasil perhitungan diatas, diperoleh persentase sebesar $88,89 \%$. Hal ini menunjukkan bahwa tidak ada perbedaan yang signifikan antara hasil keputusan menggunakan sistem dengan keputusan yang dilakukan oleh DBMP. Adapun, terdapat satu data yang bernilai false disebabkan karena penentuan pengelompokkan prioritas jalan secara manual yang dilakukan oleh DBMP tidak memperhatikan ketiga aspek yaitu biaya, kecepatan kendaraan, dan kepadatan lalu lintas. Namun, lebih mementingkan hasil diskusi tim pengambil keputusan. Sedangkan pada keputusan yang menggunakan sistem, semua aspek yang ditentukan dalam melakukan perhitungan menggunakan metode FCM diperhatikan.

\section{KESIMPULAN}

Berdasarkan hasil pengujian dan analisis sistem penentuan prioritas perbaikan jalan, maka dapat disimpulkan bahwa sistem ini mampu memberikan rekomendasi keputusan yang lebih baik dalam proses penentuan prioritas perbaikan jalan di kota Samarinda dengan menggunakan metode Fuzzy C-Means sehingga keputusan yang diperoleh lebih tepat, terkomputerisasi dan mencegah pengambilan keputusan yang bersifat subjektif. Metode FCM mampu melakukan pengelompokkan data ke dalam beberapa kelompok. Apabila kemiripan data yang satu dengan yang lain yang sangat besar dengan data lain, maka data berada pada cluster yang sama. Selain itu metode FCM memiliki hasil perhitungan yang akurat dan konsisten dimana data tetap berada pada kluster yang tepat meski pada setiap percobaan akan didapat posisi kluster yang berbedabeda dikarenakan nilai matriks partisi awal dibangkitkan secara acak.

Selanjutnya dari analisis uji hasil perhitungan yang dilakukan, untuk melihat seberapa besar perbedaan antara hasil keputusan menggunakan metode FCM dengan penentuan prioritas perbaikan jalan yang dilakukan oleh DBMP menunjukkan bahwa metode FCM mampu mengelompokkan data ke dalam beberapa kelompok secara akurat dan konsisten. Hasil penelitian ini dapat menjadi rekomendasi bagi DBMP untuk menentukan jalan yang harus diperbaiki terlebih dahulu. Perbandingan metode clustering, optimalisasi metode 
FCM menggunakan metode pengambilan keputusan seperti Simple Additive Weight, algoritma genetika merupakan rencana penelitian ke depan.

\section{DAFTAR PUSTAKA}

[1] H. L. Sari and D. Suranti, "Perbandingan Algoritma Fuzzy C-Means (FCM) Dan Algoritma Mixture Dalam Penclusteran Data Curah Hujan Kota Bengkulu," in Seminar Nasional Aplikasi Teknologi Informasi (SNATI), 2016.

[2] A. Ramadhani, A. Farmadi, and I. Budiman, "Clustering Data Cuaca Untuk Pengenalan Pola Perioditas Iklim Wilayah Pelaihari Dengan Metode Fuzzy C-Means," Jurnal Teknologi dan Industri (Diskontinu), vol. 3, no. 1, pp. 57 64, 2015.

[3] N. Menon and R. Ramakrishnan, "Brain Tumor Segmentation in MRI images using unsupervised Artificial Bee Colony algorithm and FCM clustering," in Communications and Signal Processing (ICCSP), 2015 International Conference on, 2015, pp. 0006-0009: IEEE.

[4] Z. Zhang and B. Gu, "Intrusion Detection Network Based on Fuzzy C-Means and Particle Swarm Optimization," in Proceedings of the 6th International Asia Conference on Industrial Engineering and Management Innovation, 2016, pp. 111-119: Springer.

[5] R. Vijayanandh and G. Balakrishnan, "Hillclimbing segmentation with fuzzy C-means based human skin region detection using Bayes rule," European Journal of Scientific Research, vol. 76, no. 1, pp. 95-107, 2012.

[6] Y. Zheng, B. Jeon, D. Xu, Q. Wu, and H. Zhang, "Image segmentation by generalized hierarchical fuzzy C-means algorithm," Journal of Intelligent \& Fuzzy Systems, vol. 28, no. 2, pp. 961-973, 2015.

[7] Y. Aditya Nur Santoso, "Penerapan Algoritma Fuzzy Cmeans untuk Clustering Objek Wisata," Program Studi Sistem Informasi FTI-UKSW, 2012.

[8] G. Zhu, J. Chen, and P. Zhang, "Fuzzy c-means clustering identification method of urban road traffic state," in Fuzzy Systems and Knowledge Discovery (FSKD), 2015 12th International Conference on, 2015, pp. 302-307: IEEE.

[9] T. A. Munandar and W. O. Widyarto, "Clustering Data Nilai Mahasiswa untuk Pengelompokan Konsentrasi Jurusan Menggunakan Fuzzy Cluster Means," in Seminar Nasional Aplikasi Teknologi Informasi (SNATI), 2013.

[10] L. Rusdiana, "Aplikasi Berbasis Fuzzy C-Means Dalam Penentuan Predikat Kelulusan Mahasiswa," Jurnal Ilmu Komputer, vol. 2, no. 2, pp. 1-9, 2016.

[11] R. J. E. Putra, N. Nasution, and Y. Yummastian, "Aplikasi E-Zakat Penerimaan dan Penyaluran Menggunakan Fuzzy C-Means (Studi Kasus: LAZISMU Pekanbaru)," DIGITAL ZONE: JURNAL TEKNOLOGI INFORMASI DAN KOMUNIKASI, vol. 6, no. 2, 2015.

[12] A. Ahmadi and S. Hartati, "Penerapan Fuzzy C-Means dalam Sistem Pendukung Keputusan untuk Penentuan Penerima Bantuan Langsung Masyarakat (BLM) PNPMMPd (Studi Kasus PNPM-MPd Kec. Ngadirojo Kab. Pacitan)," Berkala Ilmiah MIPA, vol. 23, no. 3, 2015.

[13] I. Irsalina, E. Supriyati, and T. Khotimah, "Clustering Gender Berdasarkan Nilai Maksimum Minimum Amplitudo Suara Berbasis Fuzzy C-Means (FCM)," Prosiding SNATIF, vol. 1, pp. 419-424, 2014.

[14] H. L. Sari and D. A. Trianggana, "Pengclusteran Data Curah Hujan Kota Bengkulu Menggunakan Fuzzy Clustering Algoritma Mixture," Jurnal Pseudocode, vol. 1, no. 1, pp. 60-71, 2014. 